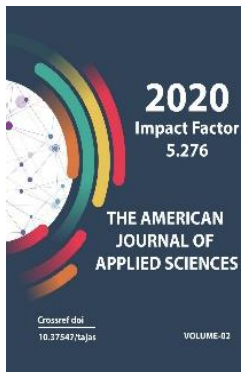

Copyright: Original content from this work may be used under the terms of the creative commons attributes 4.0 licence.

\section{Improvement Of Higher Education In The Process Of Society Digitalization}

\author{
Abdumalikov Abdulatif Abdumalikovich \\ Doctor Of Philosophy (Phd), Associate Professor Of The Department Of Philosophy, Fergana \\ State University, Uzbekistan \\ Khakimov Nazar Khakimovich \\ Doctor Of Philosophy, Professor Of The Department Of Social And Humanitarian Sciences Of \\ The Tashkent State Economic University, Uzbekistan \\ Turaeva Dinara Tolkunovna \\ Independent Researcher, Tashkent State University Of Economics, Uzbekistan
}

\title{
ABSTRACT
}

The modern problems of the formation of digital literacy of the society are considered through the created socio-economic prerequisites for the implementation of digitalization programs in the higher education system in Uzbekistan. The author claims that at the present stage of development of civil society, for the analysis of digital involvement, they allow us to fix a digital gap in the higher education system. The article shows that the implementation of the concept of continuous knowledge in the context of the digital economy becomes a reality when the most talented part of young people is selected for university studies, and the principles of openness and accessibility both in the field of higher education and information technologies are implemented. The implementation of these principles allows us to build a more flexible system of higher education, which will create the prerequisites for obtaining qualified knowledge that meets the requirements of society, a market economy, solve innovative problems in creating universal digital literacy and training competitive personnel. The author of the article offers concrete proposals for further improving the digitalization of the higher education system.

\section{KEYWORDS}

Digitalization of society, digital literacy, higher education, competitive personnel, information technology. 


\section{INTRODUCTION}

The issue of improving higher education in the process of digitalization of society is one of the current scientific problems in the development of civil society. This process is one of the priorities that will ensure a new stage of development of Uzbekistan. The social mechanism that ensures the fulfillment of this strategic task provides for the effective use of information, digital technologies, the basis and content of each individual involved in the process of continuing education at all stages of their activities, regardless of age, profession or specialty. The realization of such a social necessity is necessary for the effective participation of man in science-based, democratic reforms, the socio-cultural relations formed in the new stage of development of society, the application of modern digital technologies in human activity and social life. which is related to the creation of knowledge, professional opportunity, skill formation, socio-economic opportunity. It should be noted that the above-mentioned social and cultural factors, which are necessary for the conditions of informatization of society, do not take place evenly in the social links, including in the higher education system, in terms of cultural processes. the situation does not ensure the rapid development of the digitization process. The objective reason for this is that the professional knowledge and intellectual potential of a person differs from individual to individual, the knowledge in the indicators of professional training of the future specialist, the different levels of intelligence.

\section{RESEARCH MATERIALS AND METHODOLOGY}

The scientific novelty of the research lies in the fact that the digitization of the process of training highly qualified personnel at a new stage of development is closely linked with the task of an in-depth study of its place in the context of socio-cultural relations. This social philosophical task, in turn, promotes the digitization of the activities of all social strata in society, the ability to effectively use the opportunities of the innovative generation of information technology in the daily process in the improvement of the human factor. At the new stage of development of society, it is necessary to radically improve the training of modern personnel through intensive information, the introduction of the latest forms of the digital economy in all levels of higher education in an intensive, innovative way. This conceptual scientific task requires the main goal of university education, the phenomenon of digital advancement, which is necessary for the training of competitive personnel, qualified bachelors, masters, professors, teachers, higher education organizers to become the main content of daily activities. At the same time, in order to improve the mechanism of training qualified personnel in society, to deepen the requirements of the market economy, to deepen the study of socio-philosophical and economic aspects of the human factor, to raise this process to a new level. will be suitable. To this end, the requirements of digital education for teaching all subjects on the basis of new pedagogical technologies, its inclusion in the content of a new generation of textbooks, manuals, special literature, scientific articles, monographs, necessary to integrate its content into the thinking of future qualified personnel. should. An important feature of this process is the need to create conclusions and recommendations based on the process of assimilation of digital knowledge in the content of specialties, specialties, potential, in-depth professionalism of qualified professors and teachers, active participation in research on the digitization of higher education. The training of competent personnel in the digital economy requires not only the advancement of educational and methodological work, its modernization, but also the improvement of research work, the 
active participation of professors and teachers in the "University 3-0" program. This process, in turn, provides an opportunity for differential assessment of the activities of professors and teachers, which acts as an indicator of the effectiveness of pedagogical, research work, compliance with the requirements of digital education. There is also a need to approach the development of higher education based on the requirements of the digital economy, to improve the methodological work needed to train competitive personnel, to create a new generation of case studies for practical training in each subject, to study and compare the works of foreign scientists. During this process, it is necessary to improve the method of digitization in the content of the taught disciplines, in presenting to future professionals the current state of the country's economy, social development, scientifically based conclusions about its near future development. It should be noted that this process acts as an important bridge between higher education and practice. The main reason for this is that the main demand of the new generation of qualified personnel by employers is determined by the need to create opportunities for them to operate effectively in a digital economy in a market economy, private entrepreneurship, government agencies. The subject of the research is based on interdisciplinary methods of analysis. Such an approach is associated with the need for independent study of materials related to philosophy, economics, demography, sociology, and management, as well as the breadth and diversity of the problem we are studying, the process of formation of human activity, knowledge and professional development. Therefore, the basis of this scientific problem is the concept of "human-culture-society" based on a single network, put forward by sociologists. Also, in the current context of social stratification, the philosophical study of socio-cultural, institutional aspects of the individual's ability to effectively use higher education, the process of digitization is of practical importance. This approach is related to the analysis of the direct impact of the digitization process on the intensification of social inequality in society. Institutional aspects of the problem, the process of digitization, information technology affect the activities of social institutions and the transformation of the consciousness, worldview, transformation of competitive personnel, the formation of national, cultural values through the higher education system [1, P.222] In this regard, it should be noted the positive impact of digital technologies on the sustainable development of all segments of society.

The study of the methodological basis of the scientific problem, as stated in the Address of the President of the Republic of Uzbekistan to the Oliy Majlis on January 24, 2020, states that "in order to achieve development, we must acquire digital knowledge and modern information technologies. This allows us to take the shortest path to the ascent. After all, today in the world, information technology is penetrating deep into all areas. Although our country has risen by 8 places in 2019 according to the International Information and Communication Technologies Development Index, we are still far behind. It is true that most ministries, agencies and enterprises are far from digital technologies. "[2] In addition, the implementation of the tasks set out in the state program for the implementation of the Action Strategy on the five priority areas of development of the Republic of Uzbekistan in 2017-2021 in the "Year of Science, Enlightenment and Digital Economy" and sustainable improvement of human quality, entrepreneurship and "digital economy". The concept of creating a favorable social environment for development has important theoretical and practical significance [3]. In the new period of development of society, more than 100 decrees and resolutions of the President of Uzbekistan have been adopted 
on the priorities of the state strategy in the field of education. These documents take concrete measures to reform the education system, including higher education, and to digitize it. [4]. The task is to introduce digital technologies at all stages of the education system and increase the level of digital knowledge required for the modern economy, improve the educational infrastructure, as well as open digital education training centers in all regions of the country by 2022 within the Five Initiatives project. [5].

\section{THE MAIN PART}

Our country has developed the Digital Uzbekistan 2030 program, which includes the rapid development of the digital economy, the widespread introduction of digital technologies in all spheres of human activity, including health and education, automation of production and management systems in the real sector of the economy. and information security. Thus, "Digital economy is a system of economic, social, and cultural communication based on the use of digital technologies. It is sometimes referred to as the Internet economy, the new economy, or the web economy. "[6]. The philosophical study of the impact of information technology and the process of digitization on the development of society has deepened the analysis of the stratification of society directly, allowing to draw independent conclusions about its features in the period of objective development. In this regard, it should be noted that in studying the theoretical foundations of social development at a new stage of development, the President of the Republic of Uzbekistan said that "Poverty reduction is a complex economic and social policy to awaken entrepreneurship in the population, the full realization of human strength and potential. means to do. Therefore, I propose to develop a Poverty Reduction Program together with the World Bank, the United Nations Development
Program, and other international organizations. In this regard, it is necessary to conduct in-depth research on the basis of international norms and create a new methodology that covers the concept of poverty, its criteria, and assessment methods. "[7] In this process, the effective use of information technology and digitalization methods will be the basis for drawing scientifically and philosophically based objective conclusions about the social stratification of society. Emphasis was placed on expanding the Internet to create all the opportunities for young people to be involved in continuing education, including higher education. In particular, today 22 million people in the country use the Internet. [8]. In Uzbekistan, including 19 million people have access to the global Internet through mobile networks. In order to use the global information network in the country, the trunk telecommunications equipment has been improved. In order to further improve mobile communication in our country, 2017 communication transmission stations were installed and their total number reached 26,000 and $96 \%$ of the population had mobile communication, the level of broadband Internet access increased by 70\%. [9]. The results of the World Bank's study "Digital Dividends" show how relevant and important the digital economy is in the development of economies. In particular, a 10 percent increase in internet speed will lead to the country's GDP growth. In developed countries, the figure is 1.21 percent, while in developing countries it is 1.38 percent. This means that if the speed of the Internet doubles, GDP will increase by 13-14 percent. [10]. The use of information technology and digitalization in accordance with the requirements of social equality plays an important role in the development of society. Scientific research using the numbering methodology helps to study the causes of the level of social stratification of society, to create scientificallybased conclusions and recommendations. One 
of the factors reducing the level of social stratification is the equal access of young people to information on the global Internet. To this end, social opportunities have been created for computer networks to reach every family.

The basics of computer literacy required for future students in our country will be developed in secondary schools, vocational colleges, academic lyceums, students will be prepared to study in higher education, will learn the basics of digital technologies required for specialization. The policy aimed at creating equal opportunities for higher education and poverty reduction in our country envisages the creation of fair, equal opportunities for all members of society in the process of digitalization in information technology, social and economic relations. Ultimately, such a policy will serve to accelerate democratic reforms in society, encourage young people to pursue higher education, active participation in programs that will ensure the future of the country, intellectual activity. Therefore, at a new stage of development, the number of higher education institutions in our country has increased. "Last year, 19 new universities were opened to develop higher education, including branches of 9 prestigious foreign universities. In cooperation with leading foreign universities, training on 141 joint educational programs has been launched. A total of 146,500 students have been admitted to higher education institutions, which is twice as many as in 2016." [11]. In order to further improve and deepen the level of digitalization in higher education, "Creation of a system of management of the educational process in higher education, a database of bachelor's and master's degrees and an information system" Higher Education "for electronic student learning" A program to create an electronic database of scientific and technical data is being implemented. [12].
SOURCES AND LITERATURE REVIEW ON THE SUBJECT

The term numbering was first used in 1995 by Nicholas Negroponte, a professor at the University of Massachusetts in the United States. [13] Researchers of foreign countries have also studied the impact of information technology on the development of the information society. Priorities for the formation of the electronic culture of the individual in the information society, the problems of the subject Can be found in the work of sociologists from the Commonwealth countries, M.A. Abramova, R.V. Kamenev, V.V. Krasheninniko, V.G. Xalin [14]. A.M. Mukhtarov [15]. G.V. Chernova, E.V. Ustyujanina, S.G. Evsyukov [16]. Uzbek philosopher R.H. Ro'zieva, O.M. Muhammadalieva, S.N. Allayarova. [17] A.A. Abdumalikov, A.K. Sadikov, B.B. Iminov, I.A. Rustamov, [18] B.S. The Ganievs [19] expressed their views on improving the teaching and educational process in higher education. Analysis and results. The Ministry of Information Technologies and Communications of the Republic of Uzbekistan, Inkha University in Tashkent, Amiti University, Tashkent University of Information Technology named after Muhammad al-Khwarizmi were transferred. The main purpose of this is to keep the numbering system informed of innovations in higher education, to introduce innovative innovations in this process, information technology, training of competitive personnel in the field of digitization. [20]. It should be noted that in the world's leading countries, special attention is paid to the elimination of inequality in the digital society among the population. In justifying the level of such indicators, ie direct and indirect methods confirming the numbering among the population are used. These include the Network Readiness Index (NRI), the Global Innovation Index (GII), and the Digital Economy and Society Index. [21, B.46]. Taking 
into account the above international experience, the Republican School of Business and Management has a Doctor of Philosophy (PhD) and Doctor of Science (DSc) - Scientific and scientific-pedagogical staff in the specialty "Digital Economy and International Digital Integration" The training institute began its work. By the decision of the Higher Attestation Commission under the Cabinet of Ministers of the Republic of Uzbekistan dated August 30, 2019, the passport, the composition of the Scientific Council and the scientific seminar of the Council were approved. The Specialized Scientific Council includes scientists from the United States, China, the Russian Federation, the Massachusetts Institute of Technology, Stanford University, Hauzhong University of Science and Technology, and the Institute of Applied Information Technology. International cooperation in the training of qualified personnel, ultimately, The goal is to transform the university into an international institution for the training of highly qualified scientific and scientific-pedagogical personnel in the field of the digital economy, which is necessary to meet the needs of the Republic of Uzbekistan and foreign countries. [22]. One of the most important social and economic issues at the new stage of development is the development of national research in the field of artificial intelligence, as well as the effective reform of university education. Uzbekistan has developed a program for the implementation of artificial intelligence in 2021-2030. First of all, it is necessary to deepen the effective reform of the higher education system, as well as to accelerate international cooperation in research and education, to improve the quality and prestige of personnel in the field of artificial intelligence in the field of international competition. Priority areas include the establishment of new research and development centers, offering a set of rational solutions to the problems of economic sectors using artificial intelligence by strengthening the business-science- government integration system. It is also important to use digital products based on artificial intelligence technologies in the national economy and to have national brands that are competitive in the world market, to form a modern information society in Uzbekistan, to make the country's economic priorities a leading and competitive hub in Central Asia. support for educational reform and research activities in staff training has been identified as a key task. [23].

\section{CONCLUSION}

The impact of higher education on the digitalization process in society is of practical importance. This process is directly related to the complex of social, professional knowledge that a person has accumulated in the disciplines of university education, the quality of the specialization acquired. The activities of bachelors and masters with specialized knowledge of the digital economy are reflected in their professional skills, effective work in social processes, active participation in democratic reforms. The perfect digitalization of the university educational process is marked by the growing social demand for competent personnel in society. Uzbekistan's deep penetration into international economic systems, integration, the country's efforts to take a worthy place among the leading, developed countries by 2030, the pursuit of a leading position in Central Asia in the field of bachelor's and master's degrees, the digitization of higher education.

\section{APPROBATION}

The results of this study were presented at the Republican Scientific and Practical Conference "National Development: Current Issues of Strengthening Security, Stability and Good Neighborliness" held on November 20, 2019 at Fergana State University, May 14, 2020 at the Ural State University of Economics of the Russian Federation. International scientific- 
practical conference "Development trends of e-learning in Russia and abroad", Republican scientific-theoretical conference "Development of civil society: theory, practice and practice" held on May 15, 2020 at the Tashkent State University of Economics, May 20, 2020 The author's direct participation in the Republican scientific and theoretical conferences on "Social and philosophical problems of national, religious and political tolerance and the development of interethnic relations in Uzbekistan" was tested with reports. At the above scientific conferences, world-renowned philosophers, sociologists, sociologists, economists from the Commonwealth countries took part in the discussions and expressed their independent views.

\section{REFERENCES}

1. Abramova M.A., Kamenev R.V., Krasheninnikov V.V. High technologies: impact on social institutions and application in professional education. Novosibirsk, 2018.222 p.

2. Mirziyoyev Sh.M. Address of the President of the Republic of Uzbekistan to the Oliy Majlis on January 24, 2020 https://uza.uz/oz/politics/zbekistonrespublikasi-prezidenti-shavkatmirziyeevning-oliy-25-01-2020

3. Mirziyoev Sh. The State Program of the President of the Republic of Uzbekistan on the implementation of the Action Strategy for the five priority areas of development of the Republic of Uzbekistan for 2017-2021 in the "Year of Science, Enlightenment and Digital Economy" decree. (National Database of Legislation, 03.03.2020, 06/20/5953/0246; 27.03.2020, 06/20/5975/0377)

4. How education is being reformed in Uzbekistan.

https://vestikavkaza.ru/material/308539?ut m_source $=y x n e w s \& u t m \_$medium=deskto
p\&utm_referrer=https\%3A\%2F\%2Fyandex.u z\%2Fnews 19 июня 2020.

5. Resolution of the President of the Republic of Uzbekistan "On measures for the widespread introduction of the digital economy and e-government." National Database of Legislation, April 29, 2020, No. 07/20/4699/0520)

6. What is the digital economy? https://aniq.uz/yangiliklar/raqamliiqtisodiyot-nima.

7. Mirziyoyev Sh.M. Address of the President of the Republic of Uzbekistan to the Oliy Majlis of January 24, 2020. https://uza.uz/oz/politics/zbekistonrespublikasi-prezidenti-shavkatmirziyeevning-oliy-25-01-2020

8. Infocom.uz "The number of Internet users in Uzbekistan has exceeded 20 million" 27.01.2018.

9. Telecommunication infrastructure. Ministry of_Development of_Information_Technologies and Communications html file:///C:/Users/Admin/Downloads/Telegra m\%20Desktop

10. Jumaev N.H. Why is the digital economy necessary and what does it provide? https://review.uz/oz/post/raqamliiqtisodiyot-mamlakatimiz-taraqqiyotigarovidir

11. Mirziyoev Sh.M. Address of the President of the Republic of Uzbekistan to the Oliy Majlis of January 24, 2020 https:/uza.uz/oz/politics/zbekistonrespublikasi-prezidenti-shavkatmirziyeevning-oliy-25-01-2020

12. Resolution of the President of the Republic of Uzbekistan "On measures for the widespread introduction of the digital economy and e-government." APPENDIX 5 to the Resolution of the President of the Republic of Uzbekistan No. PP-4699 of April 28, 2020. National Database of Legislation, April 29, 2020, No. 07/20/4699/0520). 
13. NegroponteN.Being Digital. N.Y: Knopf, 1995. [Electronic resource]. URL: http://inance.ru/2017/09/cifrovayaekonomikal (date of the application: 20.07.2020).

14. Khalin V.G., Chernova G.V. Digitalization and its impact on the Russian economy and society: advantages, challenges, toffee threats // Management consulting. 2018. No 10.P. 46-62.

15. Mukhtarov A. National idea and national interest. Tashkent, "Fan", 2019.

16. Ustyuzhanina E.V., Evsyukov S.G. Digitalization of the educational environment: opportunities and threats // Bulletin of the PRUE. G.V. Plekhanov. 2018. No 1 (97) pp. 3-12.

17. Hakimov N.H., Ruziyeva R.Kh., Muhammadaliyeva O.M., Allayarova S.N. "Education system mission in the conditions of civil society development". Research article. Journal of Critical Reviews. ISSN: 2394-5125. 2020.

18. Hakimov N.H., Sadikov A.K., Abdumalikov A.A., Rustamov I.A., Iminov B.B. "Reforming the education system in the conditions of a new stage of development". Research article. International Journal of Psychosocial Rehabilitation. ISSN: 1475-7192. 2020.

19. Khakimov N.Kh., Ganiev B.S. "Improving the training of bachelors and masters in the context of the development of civil society." Economics and education. 2019 No. 6. (pp. 99-103).

20. APPENDIX 1 to the Resolution of the President of the Republic of Uzbekistan dated April 28, 2020 No. PP-4699. National Database of Legislation, 04/29/2020, No. 07/20/4699/0520)

21. Khalin V.G., Chernova G.V. Digitalization and its impact on the Russian economy and society: advantages, challenges, threats and risks // Management consulting. 2018. No 10.P. 46-62.

22. Uzbekistan will start training specialists in the field of digital economy. https://kun.uz/news/2019/og/o6/ozbekisto nda-raqamli-iqtisodiyot-sohasidamutaxassislar-tayyorlash-boshlanadi

23. A strategy for the development of artificial intelligence in Uzbekistan has been developed.

https://kun.uz/news/2020/07/13/ozbekiston da-suniy-intellektni-rivojlantirish-

strategiyasi-ishlab-chiqildi.

24. Хакимов, H. (2020). REFORMING THE EDUCATION SYSTEM IN THE CONDITIONS OF A NEW STAGE OF DEVELOPMENT.Aрхив научных исследований, (19).

25. Abdumalikov, A. A. (2019). ENVIRONMENTAL ECOLOGICAL POLICY IN UZBEKISTAN AND NECESSITY OF FORMATION OF RATIONAL COMMUNICATION TO NATURE. Scientific Bulletin of Namangan State University, 1(9), 94-101.

26. Абдумаликов, А. А. (2019). HUMAN AND NATURAL HARMONY IN THE HISTORICAL PROCESS. Scientific Bulletin of Namangan State University, 1(5), 205-209.

27. Abdumalikov, A. A. (2019). ENVIRONMENTAL ECOLOGICAL POLICY IN UZBEKISTAN AND NECESSITY OF FORMATION OF RATIONAL COMMUNICATION TO NATURE. Scientific Bulletin of Namangan State University, 1(9), 94-101.

28. Abidzhanovich, A. A. (2020). Issues of Formation Of Rationality In Relations of Nature With Society. The American Journal of Social Science and Education Innovations, 2(08), 301-304.

29. Мирзарахимов, Б. Х. (2019). КУльТУРА ТУРИЗМА КАК СТРАТЕГИЯ РАЗВИТИЯ КНИГОВЕДЕНИЯ. InПЕРСПЕКТИВНЫЕ ОБЛАСТИ РАЗВИТИЯ НАУКИ И ТЕХНОЛОГИЙ (рp. 57-58).

30. Mirzarahimov, B. (2019). The factor of good neighborhood and tourism development (Philosophical analysis). Scientific Bulletin of Namangan State University, 1(1), 140-145. 
31. Mirzarahimov, B. H. (2020). The Tasks Of Tourism In Aesthetic Education: The Harmony Of Historicity And Modernity. The American Journal of Social Science and Education Innovations,2(09), 652-658.

32. Mirzarahimov, B. (2019). The factor of good neighborhood and tourism development (Philosophical analysis). Scientific Bulletin of Namangan State University, 1(1), 140-145.

33. Mirzarakhimov, B. (2020). Tourism-is a modern means of aesthetic education. СБОРНИК СТАТЕЙ.

34. Madimarovna, A. I., \& Khoshimovich, M. B. (2020). Factors for the development of tourism culture in the uzbek national value system.ACADEMICIA: An International Multidisciplinary Research Journal,10(4), 575-580. 